\title{
Religious Fanaticism and Changing Patterns of Violent Crime in Nigeria
}

\author{
Olisa Anthony Enweonwu ${ }^{1}$, Ikenga Patrick Ugwu 2,*, Dominic Chukwuemeka Onyejegbu ${ }^{3}$, \\ Chinwe Edith $\mathrm{Areh}^{4}$ and Benjamin Okorie $\mathrm{Ajah}^{3}$
}

${ }^{1}$ Humanities Unit, School of General Studies, University of Nigeria, Enugu Campus, Nigeria

${ }^{2}$ Department of Sociology and Anthropology, Faculty of Social Sciences, University of Nigeria, Nsukka, Nigeria

${ }^{3}$ Social Sciences Unit, School of General Studies, University of Nigeria, Enugu Campus, Nigeria

${ }^{4}$ Chukwuemeka Odumegwu Ojukwu University, Nigeria

\begin{abstract}
Fanaticism has brewed into different forms in the Nigerian context - and the gravest is religious fanaticism. It has taken hold of most clans, religions, and ethnic groups across Nigeria. Religion has always existed in Nigerian societies and also has fanaticism but the level of violence precipitated by this fanaticism is apparently unprecedented. This paper journeys into the beginning of religious fanaticism in Nigeria and its changing patterns of violence. It highlights the root causes of religious violence in Nigeria and visible patterns in this violence. The paper adopted structural-functionalism theoretical formation and gathered data from textbooks, e-books, journals, online articles, newspapers, and magazines. At the end, the paper recommends that Nigerian governments initiate comprehensive programs to reconcile the religious differences that have evolved over time between Christianity, Islam, and African Traditional Religions.
\end{abstract}

Keywords: Christianity, Crime, Islam, Religious fanaticism, Religious violence.

\section{INTRODUCTION}

Religious fanaticism entails violent and unreasonable religious enthusiasm. It is an excessive irrational zeal to defend one's religion and consequently become a destructive agent of religious disharmony in the society (Sulaiman, 2016; Balogun 1988; Sulaiman 2014). In Africa, Two dominating religious faiths are Christianity and Islam (Okpa, Ajah \& Okunola, 2018). In Nigeria, the two faiths are diametrically popular with Christianity highly practiced in Southern Nigeria and Islam which is highly practiced in the North (Ajah, Okpan \& Nwokeoma, 2017; Sontag, 1990). Christians in Northern Nigeria see themselves as minorities as Moslems in the South also see themselves as minorities (Ajah, Nwokeoma \& Okpan, 2017). Neither faith has always used the notions of the minority in a positive sense, but often to imply less patronized faith, underrepresented or marginalized group (Okpa, Ajah \& Okunola, 2018). Both have used the excuse of minority, extinction, and righteous hunt for memberships to manoeuvre for domination of Nigeria's people and resources. This has been peaceful at some times and violently conflicting at other times (Ajah, Ajah \& Obasi, 2020; Ajah, Nwokeoma \& Okpa, 2017). Sometimes, minorities and divisions exist

*Address correspondence to this author at the Department of Sociology and Anthropology, Faculty of Social Sciences, University of Nigeria, Nsukka, Nigeria; E-mail: ikengapatrick15@gmail.com within each religious group along the lines of beliefs, methods of worship, and expected outcomes of eternity (Egbegi, Ajah \& Ogbonnaya, 2018). This is seen in Shiite and Sunni Moslem groups of Islam and orthodox and Pentecostal branch churches of Christianity. These divisions have always led to disparities and violent conflicts that break both constitutional laws and humanitarian principles. This paper is a journey into the root causes of religious fanaticisms in Nigeria, how the root causes have fermented violent crime patterns, and how these patterns of violent crime are changing because of changes in the root causes.

In July 2016, a Nigerian Islamic cleric purportedly ordered his followers to kill a Christian woman who does early morning preaching in her neighborhood (Ugwuoke, Ajah \& Onyejegbu, 2021; Ajah, Dinne \& Salami, 2020; Isaac, 2016). The Islamic Cleric and his followers believed their understandings of God to be pure and much more correct compared to the preaching of the Christian woman (Egbegi, Ajah \& Ogbonnaya, 2018). Even as both religions are unique in understandings of God and the meaning of sanctity in human conduct, the cleric believed the ways of Islam to be supreme and was deeply irritated by the Christian woman's understandings of God (Sahara Reporters, 2016). The cleric mounted light warnings and then proceeded to order the woman to death. In another event, 15 predominately Christian communities in the same local government area in Plateau State came 
under intense attack from an armed Moslem group in August 2018 (World Watch Monitor, 2018). A Christian reverend, his wife and children were particularly burnt alive in their church building in that attack. The attack culminated with over 230 death casualties and more than 11,500 refugees who fled their homes (Anthony, Obasi, Obi, Ajah, Okpan, Onyejegbu, Obiwulu \& Onwuama, 2021; Egbegi, Ajah \& Ogbonnaya, 2018). In each of these cases, Nigeria was not at war and neither was Islam at war with Christianity. Each was a case of a group of people who misconstrued the teachings of Islam and were motivated by this error to behave violently against other people (Okpa, Ajah \& Okunola, 2018). Countless such events have been recorded and a lot more has gone unnoticed. It usually starts from subtle and tiny places like Moslem sons disowning their fathers for being Christians or Christian brothers disowning their fellow brothers for being Moslems. From such little psychological and emotional intolerance, all forms of brutal violence brew and manifest in the bigger forms that shock the conscience of the world (Egbegi, Ajah \& Ogbonnaya, 2018; Armstrong, 2015). This is prevalent in multi-religious communities in Plateau and Kaduna states where sons murder their fathers for being Christians or for being Moslems. It all starts from these little segregations in the mind and keep growing till it consumes the conscience.

In a more drastic case, an influential Islamic cleric in Borno State called Mohammed Yunus developed his own radical belief versions of Islam. As a leader and teacher of Islamic principles, he quickly drew followers to his radical beliefs (Nnam, Ajah, Arua, Okechukwu \& Okorie, 2019; Egbegi, Ajah \& Ogbonnaya, 2018). He and his followers were locally referred to as the Nigerian Taliban because the group held similarities in beliefs and conducts as Taliban, a renowned terrorist organization (CNN, 2018). The members considered themselves as noncitizens of Nigeria and failed to participate or obey any governance system that is not based on Sharia Law. Gradually, the group recused themselves from the general Islamic teachings and gatherings in Borno State and withdrew and lived in forests (Ajah, Nwokeoma \& Okpan, 2017). In 2003, the group began peddling attacks on government properties, institutions, Christians, Moslems, women, children, and without respect or pity to anything (Egbegi, Ajah \& Ogbonnaya, 2018). In April 2014, the group orchestrated a suicide-bombing attack on a major market in Nigeria's capital that leftover 70 dead casualties and 124 casualties severely injured (BBC,
2016). Between 2002 and 2018, the group killed over 100,000 casualties and displaced over 2 million people from their homes (Sani, 2016). They divide Nigeria and humanity into infidels and faithful. Every member of their group or whoever practiced Islam to the terms of their dictate is considered faithful and every other person is an infidel - Christians, traditional worshippers, atheists, other Moslems, and etcetera (Ajah, Nnam, Ajah, Idemili-Aronu, Chukwuemeka \& Agboti, 2021; Egbegi, Ajah \& Ogbonnaya, 2018). They employ the most brutal methods and kill all nonmembers without judgment, negotiation or chance of redemption. Their operations have displaced millions and killed hundreds of thousands of people across the Lake-Chad Basin area of West Africa (Nnam, Effiong, Iloma, Terfa \& Ajah, 2021). They call themselves Boko Haram.

These constitute religious fanaticism. A fanatic is defined by Encarta Dictionary as an extremist; a holder of extreme or irrational enthusiasms or beliefs, especially in religion or politics (Okpa, Ajah \& Okunola, 2018; Encarta Dictionary). Urban Dictionary in Okpa, Ajah \& Okunola (2018) describes a religious fanatic as someone who takes a perfectly good creed and assumes that because they pretend to follow it, they are allowed to do anything they want even if they don't really follow the creed at all, usually insisting that if others do not follow their ways, they will be damned (Okpa, Ajah \& Okunola, 2018; Urban Dictionary). The errors are not usually with the principles or creeds, but with the interpretations of the fanatic. As Salman Rushdie noted in his Satanic Verses, 'From the beginning, men used God to justify the unjustifiable' (Goodreads, 2019). The same applies to religious fanatics; they use perfect religious creeds or beliefs to justify their extreme and outrageous acts. A good instance is Mohammed Yusuf who exhorts his followers to reject the state or any type of knowledge that contradicts Islam or Sharia law (Economist, 2019). Even when most states in northern Nigeria have implemented Sharia law, Yusuf insisted that his form of Sharia law was the only true form of Sharia law - and as such, killed and destroyed other Moslems that do not follow his definitions of Sharia law and Islam (Ajah, Nwokeoma \& Okpan, 2017). Others often call such acts Jihadism and brandish it as a justifiable reason for extreme forms of Islamic beliefs. The Koran explicitly stated and rejected these interpretations and acts in the name of Islam.

Among the people there is he whose discourse on the life of the world pleases 
you, and he calls on God as a witness to what is in his heart, yet he is an unyielding and antagonistic adversary. When he turns and leaves, he walks about corrupting the earth, destroying crops and livestock - God loves not corruption (Q2:204-205) - (Guardian, 2013:57).

In many corners of the world, such violent acts based on religious extremism are considered a crime as they break major parts of constitutional and human laws of all countries and people (Eze, Obi \& Ajah, 2020; Okpa, Ajah \& Okunola, 2018). In the United States, they are subtly referred to as 'hate crimes.' Federal Bureau of Investigation (FBI) considers hate crime as a criminal offence committed against a person, property, or society which is motivated, in whole or in part, by the offender's bias, against a given race, religion, disability, sexual orientation or ethnicity/national origin (Mokhtar, 2006). Such forms of violence and crime tend to involve more brutality, force, and high motivation than other forms of crime. The constitutions of the United Kingdom identifies such offences as crimes motivated by religious prejudice and are punishable by law (Nnamani, Ilo, Onyejegbu, Ajah, Onwuama, Obiwulu \& Nzeakor, 2021; UK Parliament, 2003). In many ways, religious fanaticized activities threaten Nigeria even to the level of its sovereignty. From the destruction of government properties, murder of innocent citizens to obstruction of government activities or claim of sovereignty of Nigeria's soil inside Nigeria, the Nigerian constitution is multiply breached as many crimes are committed in such acts.

The intention of this work is to understand the root causes of religious fanaticism in Nigeria by going from Nigeria to the rest of African countries, how these root causes have precipitated violent patterns, and changes in these violent patterns due to changes in root causes. This introductory section opens a window on how religion-related violence has fared in Nigeria in recent times. The first section studies the history of religious faiths in Nigeria and the emergence of the tripartite that make up the current socio-religious status quo. The second section studies colonialism and yardsticks of religious control - and emerging patterns of religion motivated violence crimes in Nigeria. The third part looks at concerted efforts being made to tame religious fanaticism and related crimes in Nigeria. The fourth part details the theoretical formation of the paper and the last part suggests possible means to curb religious fanaticism and bring order to Africa's religious front.
GENEALOGY OF RELIGIOUS FAITHS IN AFRICA

It is hard, if not impossible, to explicitly state the dates and manners in which religion came to Africa. Nigeria was discovered religious with all the beliefs, rituals and components that make up a full-fledged and functioning religious system (Igbo, 2012). Perhaps, one would agree with Edmund Burke who stated in his defense of religion that man is, by the constitution, a religious animal (Lee, 2012). Nigeria already had working religious systems before the coming of Europeans or any foreigner. These forms of religion are called African Traditional Religion (ATR).

\section{African Traditional Religion (ATR)}

Man is, by the constitution, a religious animal is the best answer to how and when religion came to Nigeria. Many folks have tried answering similar questions on the history of African Traditional Religion by implying that early Africans faced daunting challenges and conceded to the ideas of superior Supreme Being to seek help, others imply that early Africans were subdued by the awes of nature to worship natural things in their environment for favors and supernatural help (Okpa, Ajah \& Okunola, 2018). Gabriel and Hillary (2014) suggest that African Traditional Religion actually emerged as a result of early Africans responding to mysteries surrounding their environments like huge rivers and rocks, and feeling the sense to recognize a supreme creator of all things (Gabriel \& Hillary, 2014). These led to the formation of key beliefs, rituals and eventually the African Traditional Religion. At best, these are all intelligent guesses and have no scientifically compelling data on how and when African Traditional Religion began (Igbo, 2012). The difficulty in understanding how and when African Traditional Religion actually started is that there are no writings, records, museums or any form of repository that runs across centuries and depict the actual stages in the development of African Traditional Religion and its worshippers. Igbo (2012) notes that the only form of knowledge passage in African Traditional Religion is oral communication, which is ineffective, not scientifically convincing, and difficult to track. Perhaps applying scientific methods to understanding African Traditional Religion is in itself an ineffective approach, maybe there should be another method of inquiry that will effectively unveil the histories, dates, and key players of African Traditional Religion in a way that is more convincing than mere words of mouth from people in the millionth positions of a profoundly long chain of storytellers. 
The early traditional worshippers had diverse opinions and religious systems (Elu \& Prince, 2015). With wide ethnic spread across Nigeria, so were religious beliefs and traditions. The majority of people in southeastern Nigeria were Ibos and believed in the mythology of Chineke (Igbo, 2012). The cosmological analogy has it that Chineke (Chukwu) is the Supreme Being, almighty that cannot be contacted directly by the living. The living has to go through intermediaries like 'ndi mmuo' - which are spirits of dead relatives (Igbo, 2012). The 'ndi mmuo' are usually summoned or reached by high priests, who are living, in religious rituals. Thus, the interaction goes from the high priests or priestess to 'ndi mmuo' to Chineke (Supreme Being). The 'ndi mmuo' are considered lesser Gods or Beings to Chineke, the Supreme and Almighty Being (Igbo, 2012). Offerings and rituals to these Gods are done with personal belongings in the forms of farm produce, livestock, etc. In some cases, human sacrifices are made but systems for the selection of whom to sacrifice were usually very much established and accepted by a majority. The Ibo Gods preached peace, discipline, love, and goodness in human conduct (Okpa, Ajah \& Okunola, 2018). The governance systems in different enclaves were built around the deities or local religious systems of the people. The varieties were not much, but are significant at some points. The lbo land was a vast land and people lived in groups or enclaves. One enclave could have human sacrifice as a key component of its tradition while the neighboring enclave abhors human sacrifice in its tradition. The governance systems were much linked to respective religious systems (Igbo, 2012). Governance was highly democratic and conducted through elders in each family or clan and decisions were highly unanimous. People feared and respected the Gods and obeyed the peaceful commands of their religions. Interpretations of the Gods' principles were done by the high priests who were respected and are punished by the Gods if they misadvise the people. The priests usually advise the elders and leaders of the community - and the elders, more like legislative councils, make the final decisions (Igbo, 2012). With this form of the decision-making process and interpretation of Gods' wills, random misinterpretations that often lead to fanaticism did not exist. Violence was almost negligible and only existed in inter-community wars which were mostly more political than religious.

In the north, the majority of the citizens were Hausas. They lived under a governance structure that looked like a monarchial system. Each enclave had a ruling class of priestesses that dictated the wills of the Gods (Okpa, Ajah \& Okunola, 2018). Unlike the Ibo traditions, Hausa traditions had both political and religious governance headed by the priestesses. The ruling class shaped interpretations of law, good conduct, and the wills of the Gods. It is uncertain whether there was violence, killings or disagreements between the ruling class and the masses (Ajah, Nwokeoma \& Okunola, 2017). A common ATR in the region was Bori. Bori priestesses communed with the Gods in rituals employing ecstatic dance and provided healing and divination throughout the kingdom.

In Southwestern Nigeria, the Yoruba people lived under the cosmological belief that all humans who do good and help others in beneficial ways shall achieve transcendence and find their destinies in Orun-Rere (the spiritual realm of those who do good and beneficial things). Olodumare is considered as the Supreme Being and is usually worship or prayed to through a priest of divination called Babalawo (Igbo, 2012). The masses feared and respected Olodumare and misinterpretations of God's will were not common.

In the beginning, the region called Nigeria was as diverse almost as it is today. People lived in enclaves and worshipped different Gods using different rituals. A common feature is that each region and enclave feared and respected their Gods, interpretations of wills of God came from respected high priests who are believed to be punished if they misadvise the people. Thus, random misinterpretations that often lead to extreme or fanatic beliefs did not exist. Most of the religions preached peace, love and good conduct - and people believed, obeyed, and lived in relatively more peaceful environments from religious violence.

\section{Coming of Islam}

Islam is noted to have visibly arrived in Nigeria in the $11^{\text {th }}$ and $12^{\text {th }}$ centuries through trade, migration, and travels of Islamic wanderers and scholars. It is rumoured that the old cities of Kanem and Bornu had been in contact with Islamic traders since as early as the $9^{\text {th }}$ century, but many records are consistent with the $11^{\text {th }}$ and $12^{\text {th }}$ centuries as the time Islam was visibly noticed in northern Nigeria (Kettani, 2004). As Islam spread, it connected many converts in northern Nigeria to a network of Islamic worshippers that ran across the whole of North Africa down to the Middle East. Arabic was the major language of Islam and it quickly became the central language of trade and commerce across the borders in northern Nigeria. During the $15^{\text {th }}$ century, the 
Malian Songhay Empire spread tentacles to Northern Nigeria's Hausaland and established a dynasty under Askiyya Muhammad (Harvard Divinity School, 2019). Trade brought the Hausa people to flourishing central cities like Kano and Hausa quickly became an important language in Kano to help locals communicate with the new traders. Hausa and Arabic became very popular languages for trade, Islamic literature and scholarships (Egbegi, Ajah \& Ogbonnaya, 2018). Islam spread and people became connected to Islamic scholarships, literature and intellectual networks (Kettani, 2018). For several centuries, Askiyya Muhammad dynasty provided peace, spiritual supports, and security. The dynasty spread with Islam and reached considerable corners of the north.

In the $19^{\text {th }}$ century, Usman Dan Fodio led a Jihadist war against religious syncretism in the north proclaiming Islam as the only true form of religion and Allah as the only true God. Dan Fodio's principle was simple, convert to Islam or die (Kettani, 2004). He replaced Askiyya Muhammad and founded the Sokoto Caliphate. He fought against perceived injustices prevalent in the reigning dynasty. His wars quickly gained ground and spread across the greater north and other regions that would later become Nigeria. Dan Fodio's style of Islam was more brutal and violent than the earlier dynasty of Askiyya Muhammad (Kettani, 2004). Dan Fodio employed coerced conversion while earlier dynasties preferred more subtle methods. After the death of Dan Fodio in 1903, his aggressive methods of Islam were further propagated by his brother and son. In the same century, other individuals with even more aggressive and violent versions of Islam emerged (Ademolekun, 2018). There was the Maitatsine Movement propagated by Mohammed Marwa. He was born in northern Cameroon and migrated to Nigeria in 1945 where he started his controversial preaching on the Qur'an (Cavanaugh, n.d). Marwa spoke against the use of cars, watches, radios, and possession of money more than necessary. These ideologies were twisted and used as bases to attack government institutions, ordinary Nigerians, and every other thing that is not the Maitatsine Movement. By 1972, the movement had built an impressive number of militant followers called Yat Tatsine. In 1980, Yat Tatsine's violent attacks on other religious figures and police attracted the attention of the Nigerian army (Crenshaw, 2000). With the army's involvement, more than 5000 lives were lost including the life of Mohammed Marwa. After Marwa's death, his movement was continued by his followers and intensified with more violence. Their riots caused the death of over 3000 people in 1984, also killed 1000 in Yola and displaced about 6000 (Ademolekun, 2018). Other incidents of death and violence against the public were incited by the group. The major leader of the Maitatsine Movement was arrested in 2014 in what is hoped to be a successful tame of the horror. Besides the Dan Fodio movement and Mohammed Marwa, other theories and brutal versions of Islam has also emerged like the Izala Movement, Darul Movement, Boko Haram, etc. There are absolute differences between these movements at some points, the only relative difference at others points and zero difference at others. For instance, the Dan Fodio Movement and Boko Haram may not be totally comparable but they all started with ideologies and crafting a unique version of Islam - which may be extreme and violent versions (Egbegi, Ajah \& Okunola, 2018).

What is notable is that each version of Islam is highly connected to the governance system of the group or area where it exists. The head of the movement is usually the political and religious leader of such groups and rules as he wishes and twists mainstream ideas to suit his desires. The members usually believe the teachings not from shared beliefs but from the interpretations of the leader. Violence is usually less within each movement but intense and brutal between the members of the group and nonmembers (Crenshaw, 2000). In each case, the first step to the formation of any extremity in Islam is to reject the teachings of all other Islamic believers, then divide humanity into believers and infidels.

\section{Coming of Christianity}

Trade brought Christianity to Nigeria in the $15^{\text {th }}$ century. It was first introduced in the form of Roman Catholicism by Portuguese traders. This first wave of introducing Christianity to Nigeria was unsuccessful. The second wave came in the 1800s with the return of Roman Catholic Missionaries. It came to Benin Kingdom, it failed - then came to Itsekiri Kingdom, it succeeded. The first major convert of the Roman Catholic Missionaries was the son of Olu of Warri who got baptized and renamed Sebastian (Vivian, 2018).

African Traditional Religion was already established before the coming of Christianity. Locals received the new beliefs with skepticism and disinterestedness. The local elders and chiefs were more interested in guns, goods and trade than the chants of Christianity (Igbo, 2012). The missionaries applied no pattern of force or 
coercion - and lived side-by-side with Nigerians without locals' concern on what Christianity meant (Igbo, 2012). Sebastian of Warri later became the Olu of Warri and gave considerable entry support to the missionaries. However, unlike Northern Nigeria, Southern Nigeria was largely democratic and decentralized. The views of the king or Olu do not necessarily dictate the views of the elders or final decisions in a community. Christianity did not yet make much progress in entering Nigeria. The game-changer was black missionaries who were former slaves from Nigeria that returned home with the missionaries to preach Christianity (Deji, 2019; Ademolenkun, 2018). Locals chiefs and families saw people like them that speak their language - and started listening. Christianity started gaining plausibility and spread quickly through Southern Nigeria. The missionaries started making changes to matters that touched the nerves of African traditions like the killing of twins, polygamy, human sacrifices, etc and promoted campaigns to end such traditions. This started creating divisions within existing community structures and within the churches (Fitzduf, 2014). Some prospective converts became stalled by the ideological conflicts and a few converts saw the teachings as if though the church was trying to control them. Southern Nigerians were accustomed to independence in leadership and thinking - any act or gesture to gain absolute control of another person seemed irritating at best (Ademolekun, 2018). It seemed as the Europeans and Americans were controlling the locals both politically and ecclesiastically. The African Christians rebelled, broke away from the European churches and started forming their own churches. These movements brought major restructuring to Christianity models in Nigeria. Samuel Ajayi Crowther, a former slave from Yoruba land, formed his St. Peter's Church in 1853. Christ Church Army was carved away from Anglican Church in 1910. A few other churches also carved away from Christ Church Army with their own philosophies (Deji, 2019). Revolutions did occur in the trends of Christianity in Nigeria - but at no point was this engulfed in violence or killing or physical fights like the revolutions of Dan Fodio and few other Islamic clerics after him. Thus, the history of Islam and Christianity in Nigeria took separate parts - one violent and the other peaceful.

\section{A TRIPARTITE STATUS QUO}

The history of religion in Nigeria started with the African Traditional Religion even though no particular date or timeline can be assigned to its beginning. In early Northern Nigeria, the systems of African
Traditional Religion very largely controlled governance. In the South, the systems of African Traditional Religion had a huge influence on governance but not to a very large extent (Ademolekun, 2018). The legislature-styled governance system in Southern Nigeria made religion a second-tier and subjective to the final decisions of the elders (legislators). Islam came in the $9^{\text {th }}$ century and Christianity in the $15^{\text {th }}$ century. Islam was introduced to Northern Nigeria and Christianity to Southern Nigeria - and both competed with Africa Traditional Religions in each region for ascendency (Deji, 2019). Islamic promoters consistently used force, violence and killings to spread their faith in the north. Their motto was simple, 'convert to Islam or die.' This initial creed set a violent-styled tradition for Islam and subsequent promoters of Islam in Nigeria have employed violence in different forms and for different reasons to achieve their goals (Eze, Ajah, Nwonovo \& Atama, 2021; Ademolekun, 2018). Promoters of Christianity employed 'chatty-styled' conviction method instead, talked to people about Christianity and hoped that they convert to Christianity. However, the teachings of Christianity had much contrariety with local traditions of many communities in the South - and some point, created arguments, anger or hatred between converted community members and non-converted community members. It is expected that such ideological conflicts should have created major violent scenarios at some points, but extensive records of such violence do not exist or are not easily accessible.

A natural dichotomy took shape; Islam in Northern Nigeria, Christianity in Southern Nigeria, and patches of Africa Traditional Religion spread across all regions. The division is not intentional, but apparent, and has evolved over time. According to a survey by Pew Forum in 2010, the Nigerian population is $48.8 \%$ Islam and $49.3 \%$ Christianity (Rolando, 2017). Almost 50-50 division, then the rest of the population belong to other religions mainly African Traditional Religions. This forms a tripod arrangement of Christianity, Islam, and African Traditional Religion as the main religious components in Nigeria.

\section{SOCIO-POLITICAL CONSTRUCTS OF RELIGIOUS DEVELOPMENT IN NIGERIA: BEFORE AND AFTER}

In early Nigerian societies when the political arrangement called Nigeria was nonexistent, people lived in patches and a socio-political construct was uniquely associated with each patch (Ademolekun, 2018). Each socio-political construct was shaped by 
political, religious, and social norms. The constructs determined how people lived, imagined their futures and were governed (Okpa, Ajah \& Okunola, 2018). In the Warri Kingdom, for instance, the decision of who becomes the Olu of Warri was partly determined by religious rituals. In all other patches, religions were parts of traditions and further shaped every aspect of human life from political behaviors to social relationships (Achunike, 2008). Understanding how these constructs are shaped is fundamental to understanding the root causes of violence and religious fanaticism in Nigeria.

\section{CAUSES OF RELIGIOUS VIOLENCE IN EARLIER NIGERIA}

A key determinant of how societies are influenced in any age is needs of the society; based on the needs of the masses, a particular social norm, religious belief, political or leadership structure would survive or get completely waned (Ajah \& Onyejegbu, 2019; Ajah \& Ugwuoke, 2018). These needs vary from society to society and age to age. It could be a need for land to farm or joke to laugh; or it could be a need for infrastructure to support industry or swimming pools for relaxation (Chris, 2006). In Maslow's work on the theory of needs, he identified physiological needs like needs for food, water, air and sleep as basics that man cannot survive without. Such needs were prevalent with early Nigerians and shaped the socio-political constructs of their time (Okiro, 2005). Since early Nigerians were peasant farmers, they did not have the technologies to control or predict rain and many aspects of their farming needs. Like all problems they could not solve, they resorted to religion and believed in God to solve their problems (Olalekan, Olokor, Hanafi \& Charles, 2018). Other critical issues like infertility or delays in birth, health failures, low intensity of the wind, they worshipped and prayed to their Gods for help. The high priests were always the points of contact with the Gods - and in key communal issues, the high priests advised the kings and elders. Political control remained with the kings and elders but religion held much sway that the high priests also influenced the masses and key decisions (Areh, Onwuama \& Ajah, 2020; Wantu, 2018). With this level of communal process in decision-making, misinterpretation of religious laws or rituals was unlikely. Often religious rituals and beliefs did bring divisions in some families; beliefs like the view of twins as a curse, human sacrifice, etc. But the majority did believe in such rituals, and the few victims of such crudeness could neither resist nor justify them as crimes at the time.
Fears and hopes for eternity are other factors that religion used to shape the socio-political constructs of early Nigerians (Ademolekun, 2018). Each patch had an established belief on the origin of the earth and what happens after death. This brought a sense of need for people to secure a place for themselves and their families by following the commands of religion (Iheanacho, 2009). In places like lbo land, the dead were respected and believed to help and protect their families. People aimed to secure good names and positions after death by absolutely observing religious rituals and commands.

With complete loyalty to religious beliefs, the masses were easily governed and no misinterpretation of religious commands significantly affected the people or patterns of worship. The complete loyalty benefitted the kings and rulers since the synchronicity kept governance very simple and easily controllable. The rulers had little opposition and there was no motivation to misinterpret or influence the misinterpretation of the Gods' commands (Wantu, 2018; Olalekan, Olokor, Hanafi \& Charles, 2018). In places in the north, the ruling class was established and no opposing force existed. In southern Nigeria especially in Ibo land, the eldest in families were respected and they represented their families in governance and decision-making for the patches. Thus, there was zero conflict between existing political structure and religious structure - and masses wholeheartedly accepted both the religious and political order. Hence, about zero religious violence existed.

\section{CAUSES OF RELIGIOUS VIOLENCE IN RECENT NIGERIA}

Just like in early Nigeria, the 'need' factor also plays a role in the socio-political constructs of modern societies. What people need or want, and what is considered important by any sect of people generally affects the causes of religiously motivated violence in that society (Okiro, 2005, Achunike, 2008). From the early Nigerians till date, the components of needs in Maslow's theory of needs still largely exist but other new elements of wants have also emerged. The new elements emerged as a result of many changes in the societies that have affected the socio-political constructs of all the earlier patches or enclaves (Ajah, Uwakwe, Nwokeoma, Ugwuoke \& Nnnamani, 2020; Ajah \& Okpa, 2019; Ajah, 2018). An example is the coming of foreigners in the north and south who brought new lifestyles and expectations to Nigerian societies (Okiro, 2005). Such new lifestyles and 
expectations of life meant that locals will expect new things from the political and religious arrangements in their local societies - and these may not easily be provided since the local arrangements or leaders have no experience in providing such foreign expectations (Olalekan, Olokor, Hanafi \& Charles, 2018). Thus, changes will occur in the local arrangements that will not be absolute or instant but will be considerably visible. Maslow's physiological needs of water, food, health and air are still basically needed and given priority in recent Nigeria. However, new elements such as want of political power and religious domination exist and play new roles. Unlike in early societies where the patches were homogenous, recent Nigerians went through a colonial leadership that unified the patches and created a huge heterogeneous state with nonmatching experiences, religious beliefs, social arrangements, and expectations of life (Achunike, 2008). This new socio-political arrangement also means that Nigeria contains those multifaceted earlier patches with different elements that affect their need factors. New needs like wants to dominate the new union now exist - this is only because the society is now heterogeneous unlike in early Nigeria where homogeneity was steady since there was no unification and people lived in small groups (Egbegi, Ajah \& Ogbonnay, 2018). A good picture of this struggle or want to dominate is captured in the comments of Ahmadu Bellow, Sultan of Sokoto and Premier of Northern Nigeria who urged people in the North in the following words, "The new nation called Nigeria should be an estate of our great grandfather Uthman Dan Fodio. We must ruthlessly prevent a change of power. We use the minorities in the North as willing tools and the South as a conquered territory and never allow them to rule over us and have control over their future" (Deji, 2019; Okpa, Ajah \& Okunola, 2018; Francis, 2017). Want of domination has influenced the sociopolitical arrangement which is now propagated through religion and created a new model of intolerance. Since northern Nigeria is largely Islamic, they want to dominate the unification with Islam exists and has created bases for extreme behaviours (Olalekan, Olokor, Hanafi \& Charles, 2018). Christianity also poses intentions to spread its beliefs and recruit new members but the approach of Christians to finding and recruiting members explicitly abhors coercion and violence. This is unlike Islam whose historical interpretation allows room for coercive recruitment. Many Islamic clerics in the north embraced the historical possibility that Islam might permit coerced recruitment to preach violent annexation of lands and carnage of non-Islamic believers to followers with backings from Islamic scriptures even when the referenced scriptures are misinterpreted (Emeh, 2011). This is seen in the cases of Boko Haram, Izala Movements, and other sects that have violently attacked other people or government agencies in Nigeria.

The leadership model in the new unification is also novel and allows people to easily change role models and religious figures (Henry \& Peter, 2018). The earlier people that lived in smaller societies had few religious leaders that interpreted religious laws and rituals - and there were no easy means to find or connect with similar cultures or more aggressive versions of their cultures. The implication is that even if anyone developed more radicalized versions of the religions at the time, it will be difficult to find support or followers since no connecting precedence existed (Wantu, 2018; Achunike, 2009). But with trade across the border in northern Nigeria and the coming of colonialism, these patches were exposed to foreigners and extremist ideas that could have failed hitherto now find references, supports, and sympathizers - and found acceptance to grow. This is seen in the case of Mohammed Marwa who was initially from Cameroon and was able to reference experiences in both Nigeria and Cameroon to establish the Maitatsine Movement in northern Nigeria, then people in Nigeria that probably had once thought of more radical versions of Islam in any similarity with the Maitatsine Movement now easily found leadership in Mohammed Marwa - a diversity system that did not exist in the smaller groups of an earlier era.

\section{PATTERNS OF VIOLENT CRIME}

The root causes of religious violence in Nigeria have also precipitated patterns of violence that have existed centuries after centuries since the beginning of human existence. In the beginning, before Nigeria had contacts with foreigners, religious violence existed on an Interest-Based Pattern.

Interest-Based Pattern is a pattern of violence that is witnessed by people with conflicting interests who rather employ religious narratives as bases for their violence. In early cultures, people lived side-by-side in small groups and each group had unique religions and leadership structures. Due to the size of the groups, each group was highly homogeneous and chances of conflict or violence were minimal. Nonetheless, stories still abound of violence between groups and between 
leaders in each group (Emeh, 2011). Such violent scenarios were more political than religious but were often propagated with religious chants and rituals. In lbo land, far down Southern Nigeria, the religious tradition covered everything. People hardly did anything without consulting or referencing 'Chineke' or 'Ndi Mmuo (Igbo, 2012).' The effect is that - once the warriors or fighters are convinced by the high priests that the opponents must be killed, the fighters go to war with much energy and almost get fanatic with killing or destroying the opposing groups (Olalekan, Olokor, Hanafi \& Charles, 2018). This was the first form of religious fanaticism and was obvious in wars that were mostly political. There is no record of any ancient religion in Nigeria that preached the killing of people in other groups as a key ritual or permitted such interpretations. More often than not, wars in the early days emerged from failed negotiations, pride, interests - desire to subjugate groups. Once the wars have commenced, fighters and warriors are then decorated with religious beliefs to the extent of being fanatic in killing opposing groups.

\section{CHANGES IN PATTERNS OF VIOLENCE}

Since the coming of foreigners with Islam and Christianity, many changes in the socio-political landscape of Nigeria have occurred. The small groups that occupied the geographical area currently called Nigeria have become politically unified under one government and most cultures have become mixed with other cultures (Achuike, 2009). The Interest-Based Pattern of violence still exists in this later stage of Nigeria but with changes in interest and models of propagation. Islam and Christianity came with much multi-polarity in religious leadership. Unlike in the early days when high priests were few and a series of processes are required for anyone to become a high priest, in recent times; anyone can call himself a pastor, priest or Imam over a period of a night. It has become too easy for anyone to attain the level of religious leadership without a set qualification, training or set of achievements. This created a careless multipolarity in religious leadership and allowed many interpretations and interests to religious laws and doctrine (Okpa, Ajah \& Okunola, 2019). Thus, anyone that sees an opportunity in destabilizing an existing system simply hires others to build followership through distorted religious teachings and then unleashes violence to the extent of a total breakdown in the social order (Olalekan, Olokor, Hanafi \& Charles, 2018). While some hire others to establish violence, others build the followership by themselves and initiate violence. There is no particular instance that can be cited to this theory but a key question that exemplifies it is - "how do religious violent groups like Boko Haram or killer herdsmen raise money to buy weapons, ammunition, and other essentials that make their existence and successful operation possible?'

Method-Based Patterns emerged in recent times. It came as foreigners brought their religions to Nigeria and established considerable acceptance of these religions across diverse groups (Wantu, 2018). Those who assimilated the different new religions began to behave differently from other people and worshipped differently. Nigeria, as we know it, became filled with different people, with different lifestyles and different modes of worship. It was at this time that Uthman Dan Fodio initiated his war against syncretism and made people in northern Nigeria to either convert to Islam or be killed (Okpa, Ajah \& Okunola, 2018). This pattern of violence still exists today in diverse forms. An instance is the Imam in Abuja who recently ordered his followers to murder a woman because she was Christian. When there is a difference in the method of worship, there are usually also differences in lifestyle (Olalekan, Olokor, Hanafi \& Charles, 2018). When people of one religion cannot tolerate the sight of this difference and proceed to unleash violence on other people based on this difference, such a scenario is a Method-Based Pattern of religious violence. It is particularly difficult to know whether Boko Haram or Izala or any of the existing religiously violent groups belong to this pattern (Egbegi, Ajah \& Ogbonnaya, 2018). This reason is that their aims are rarely stated, often changes or are totally incomprehensible. It is however more plausible to believe that some members of such groups joined because of their intolerance of religious differences in their communities. Method-Based Pattern emerges from the want of people to dominate their environment and other people in it with their own views and ways of life. When such a goal is pursued to the level of fanaticism, a brutal model of serial killing is unleashed against other religions or cultures in communities.

Need-Based Pattern is a recent pattern that emerged as societies separated governance from religion (Egbegi, Ajah \& Ogbonnaya, 2018). In earlier days, when it fails to rain or the sun gets too hot, people do not blame their leaders but pray to their gods for forgiveness and help (Olalekan, Olokor, Hanafi \& Charles, 2018). At the time, people looked to their gods for solutions but at the guidance of the leaders. With the coming of foreigners and the unification of Nigeria, governance became separated from religion and 
people started looking to their leaders for solutions to their problems. When the governments fail to provide a solution, individuals with ideas emerge, selling distorted and extremist ideas as causes of the problems and violence as a solution; promising wealth, stability, and favor from God (Egbegi, Ajah \& Ogbonnaya, 2018). People then follow; out of hunger, poverty, and frustration. Such patterns can be seen in the far north where poverty can be extreme and sickness can be severe. Violence emanating from this model is usually seen by perpetrators as the only means of survival, as such, very brutal and merciless.

\section{THEORETICAL FORMATION}

Structural functionalism is the theoretical framework. The functional approach in Sociology was borrowed from the analogy of organism in the biological sciences in which all the body organs, in any living organism, have a kind of interconnectivity that links them together. Each of these organs plays a certain role in the survival of the organism. In any situation where any of the organs malfunctions, it is believed that this malfunctioning might affect the life of the organism Auguste Comte and Herbert Spencer (Eteng, Echiegu, Eteng, Okereke, Otu \& Nweke, 2007).

In this view, the functionalists, therefore, argue that society is made up of groups and institutions which constitute the whole. They state further that each of these institutions that form the society plays a part in the survival of the system. From the foregoing, functionalists view society as a system, a set of interconnected parts which, together form a whole. This makes society the primary unit of functional analysis. The focus of attention is how the basic parts of the society, that is, the various institutions, such as the military, police, religious organizations, family, political, economic, legal, and educational institutions co-relate and function for the survival of the entire society (Ajah, Nwokeoma \& Okpan, 2017). Indeed, the failure of political leaders to deliver on their campaign promises has escalated the incidence of religious violence in Nigeria thereby threatening the peaceful coexistence of the country. The country is gradually degenerating into Hobbesian State which was characterized by anarchy, nasty and brutish.

Other root causes like the interests of religious leaders and intolerance by worshippers have also precipitated huge violence among each religion and outside religions as well. All these elements create a violent system that affects the whole of Nigeria.
Religion is a key functional part of Nigerian society that has the capacity to swiftly influence the whole parts of the Nigerian society with peace or violence - and addressing religious violence is one key way of addressing general violence in Nigeria.

\section{SOLUTION TO RELIGIOUS VIOLENCE IN NIGERIA}

To address religious violence in Nigeria and Africa, the root causes have to be strategically targeted and dismantled. Two possible approaches are; a unification program that would reconcile the differences between/inside religions and extensive care by governments to address the basic needs of citizens. Most people choose violence as an optional alternative to poverty. Government should endeavour to provide basic infrastructure and a healthy economy that will create jobs and enable people to live up to basic standards - and not fall prey to external interests or radical ideas that feed on poverty in order to get people to do their violent biddings. Since the unification of the small groups that make up Nigeria and other Africa countries, differences and frictions are expected. These differences often brew to become a large basis for violence and religious killings. A comprehensive program by government officials to identify key points of differences between cultures and religions, and bring reconciliation to these differences will positively establish a strong foundation of peace in Nigeria and Africa.

\section{CONCLUSION}

Man is, by nature, a religious animal. That insinuates that religion did not come to Nigeria or Africa with the foreigners. It has always existed and been part of the African people and systems. Foreigners brought Islam and Christianity to Nigeria - and both religions have made many changes in the Nigerian people and lifestyles. Early Nigerians, who practiced African Traditional Religion, had little or no religiously motivated violence compared with later Nigerians after the coming of Islam and Christianity. This paper has journeyed into the root causes of these changes and identified needs, interests, and methods at the basis of these changes. The changes also precipitated changes in patterns of violence which the paper identified and studied. It also recommends extra efforts by governments to alleviate poverty and help people provide for their needs, and intentional efforts to reconcile religious differences as major steps to curb religious violence in Nigeria. 


\section{DECLARATION OF CONFLICTING INTERESTS}

The author(s) declared no potential conflicts of interest with respect to the research, authorship, and/or publication of this article.

\section{FUNDING}

The author(s) received no financial support for the research, authorship, and/or publication of this article

\section{REFERENCES}

Achunike, H. C. (2008). Religious practices in Nigeria as source of social conflict. Journal of Liberal Studies, 12 (1\&2), 286-295.

Ajah, B. O, Uwakwe, E. E., Nwokeoma, B. N., Ugwuoke C. O., \& Nnnamani, R. G. (2020). Ameliorating the plight of awaitingtrial inmates in Ebonyi State, Nigeria through reasonable bail condition. Pertanika Jounal of Social Sciences \& Humanities, 28 (4), $2897-2911$

https://doi.org/10.47836/pjssh.28.4.22

Ajah, B. O. (2018). Educational training of inmates in Awka and Abakaliki Prisons, Nigeria Journal International Journal of Criminal Justice Sciences. 13 (2), 299-305

Ajah, B. O., \& Okpa, J. T. (2019). Digitization as a solution to the problem of awaiting-trial inmates in Ebonyi State, Nigeria. International Journal of Criminal Justice Sciences, 14 (2), 199-207.

Ajah, B. O., \& Ugwuoke, C. O. (2018). Juvenile Justice Administration and Child Prisoners in Nigeria. International Journal of Criminal Justice Sciences, 13 (2), 438-446.

Ajah, B. O., Nnam, M. U., Ajah, I. A., Idemili-Aronu, N., Chukwuemeka, O. D., \& Agboti, C. I. (2021). Investigating the awareness of virtual and augmented realities as a criminal justice response to the plight of awaiting-trial inmates in Ebonyi State, Nigeria. Crime, Law and Social Change.

https://doi.org/10.1007/s10611-021-09988-5

Ajah, B. O., Nwokeoma, B. N., \& Okpan, S O. (2017). Socioeconomic implication of kidnapping and hostage taking in Southern Nigeria. Journal of Law and Judicial System, 6 (2), 51-59.

Ajah, B.O., Ajah, A.I., \& Obasi, C. O. (2020). Application of Virtual Reality (VR) and Augmented Reality (AR) in the Investigation and Trial of Herdsmen Terrorism in Nigeria. International Journal of Criminal Justice Sciences, 15 (1), 1-20.

Ajah, B.O., Dinne, C.E., \& Salami, K. K. (2020). Terrorism in Contemporary Nigerian Society: Conquest of Boko-Haram, Myth or Reality. International Journal of Criminal Justice Sciences, 15 (1), 312-324.

Ajah, O. B., \& Onyejegbu, D. C. (2019). Neo-Economy and Militating Effects of Africa's Profile on Cybercrime. International Journal of Cyber Criminology, 13 (2), 326-342.

Anthony, E.O., Obasi, C.O., Obi, D.O., Ajah, B.O., Okpan, O.S., Onyejegbu, C.D., Obiwulu, A. C., \& Onwuama, E. M. (2021). Exploring the reasons for perennial attacks on churches in Nigeria through the victims' perspective. HTS Teologiese Studies/Theological Studies, 77(1), a6207. https://doi.org/10.4102/hts.v77i1.6207

Areh, C. E., Onwuama, E. M., \& Ajah, B. O. (2020). Social consequences of wife-battering in Ogbaru and Onitsha north local government areas of Anambra State, Nigeria. FWU Journal of Social Sciences, 14 (4), 80-92. https://doi.org/10.51709/FW12727

Armstrong, K. (2015, March 10). The myth of religious violence. Tricycle. Retrieved from http//www.tricycle.com.
Balogun, K.A. (1988). Religious fanaticism in Nigeria: problems and solutions. In Balogun, I.A.B. et. al. (eds.): The place of religion in the development of Nigeria Ilorin. Ilorin: Department of Religions, University of Ilorin .

BBC News. (2016). Nigeria violence: More than 70 killed in Abuja bus blast. Retrieved from https://www.bbc.com/news/worldafrica-27018751

Cavanaugh, W. T. (n.d). Does religion cause violence? Retrieved from http://bulletin.hds.harvard.edu.

Chris, O. (2006, October 7). Herdsmen kill parishioners; seek death of businessman Victor Nwankwo. Vanguard, P45.

CNN. (2018). Boko Haram Fast Facts. Retrieved from https://edition.cnn.com/2014/06/09/world/boko-haram-fastfacts/index.html

Crenshaw, M. (2000). The psychology of terrorism: an agenda for $21^{\text {st }}$ century. In Political psychology, 21, 404-420. https://doi.org/10.1111/0162-895X.00195

Deji, O. (2019). Christianity in Nigeria. Retrieved from https://the234project.com/arts-and-culture/nigeria/christianityin-nigeria/

Economist. (2019). The fight against Islamic State is moving to Africa. Retrieved from https://www.economist.com/middleeast-and-africa/2018/07/14/the-fight-against-islamic-state-ismoving-to-africa

Egbegi, F. R., Ajah, B. O., \& Ogbonnaya C. (2018). combating boko haram insurgency through a superior ideology: the role of the federal government. European Journal of Political Science Studies, 1 (2), 13-22.

Elu, J., \& Prince, G. (2015). The Causes and consequences of terrorism in Africa. The Oxford Handbook of Africa and Economics. https://doi.org/10.1093/oxfordhb/9780199687114.013.16

Emeh, O. (2011, 5 January). Analysing Nigeria's current crime surge The Vanguard, P61.

\section{Encarta Dictionary}

Eteng, I. A., Emma-Echiegu, N., Eteng, M. J., Okereke, O. J., Otu S., \& Nweke, J. O. (2007). Fundamentals of sociology. Larry \& Caleb Publishing Ltd

Eze, O. J., Obi, D. O., \& Ajah, B. O. (2020). Nigerian criminal justice system and victims of crime neglect in Enugu Urban. FWU Journal of Social Sciences, 14 (3), 41-53. https://doi.org/10.51709/FW1272J/fall2020/4

Eze, O.J., Ajah, B.O., Nwonovo, O. S., \& Atama, C.S. (2021).Health sector corruption and COVID-19 outbreak: evidence from Anambra and Enugu States, Nigeria. Journal of Contemporary African Studies. https://doi.org/10.1080/02589001.2021.1921129

Fitzduff, M. (2011). Just enough to hate - not enough to love. Washington DC: Georgetown University Press, P.147.

Francis, A, O. (2017, August 23). Amalgamation of Nigeria in 1914 is not the "will of god". Vanguard Newspaper, p63

Gabriel, T, W., \& Hillary, C. A. (2014). Religion: Past and Present in Nigeria. International Journal of Sciences: Basic and Applied Research (IJSBAR), 17 (2), 156-174.

Goodreads (2019). Fanaticism Quotes. https://www.goodreads.com/quotes/tag/fanaticism

Harvard Divinity School. (2019). Islam in Nigeria. Retrieved from https://rlp.hds.harvard.edu/faq/islam-nigeria

Henry, U., \& Peter, D. (2018, 23 April). Killings: Senate summons Buhari as herdsmen attack another Benue church. Vanguard Newspaper, p48.

Igbo, P. (2012). Treasure of Difference. Enugu: Clacom, P10.

Iheanacho, N. N. (2009). A critical look at Contemporary Nigerian Christianity. International Journal of Theology \& Reformed Tradition, 1, 104-117. 
Isaac, I. (2016, June $13^{\text {th }}$ ). Islamic cleric ordered youths to kill female preacher. This Day, P43.

Kettani, H. (2004). Muslim population in Africa: 1950 - 2020,' International Journal of Environmental Science and Development, 1 (2), 1-13.

Lee, W. (2012). Burke was right: man is a religious animal. Retrieved from https://leeware.wordpress.com/2012/03/08/burke-wasright-man-is-a-religious-animal/

Mokhtar, B. B. (2006). Religion, Religious Fanaticism and Hate Crimes in the United States. Cairn Info. Revue française d'études américaines, 110 (4), 107-121. https://doi.org/10.3917/rfea.110.0107

Nnam, M. U., Ajah, B. O., Arua, C. C., Okechukwu, G., \& Okorie, C. O. (2019). The War must be Sustained: An Integrated Theoretical Perspective of the Cyberspace-Boko Haram Terrorism Nexus in Nigeria. International Journal of Cyber Criminology, 13 (2), 379- 395. https://doi.org/10.1007/s12144-021-01680-0

Nnam, M.U., Effiong, J.E., Iloma, D.O., Terfa, I.M., \& Ajah, B.O. (2021) Hazardous drinking and the dark triad: an antidote for manipulative behaviour among students. Current Psychology, 40(4), 1-7.

Nnamani, G.R., Ilo, K.O., Onyejegbu, D. C., Ajah, B.O., Onwuama, M. E., Obiwulu, A. C., \& Nzeakor, O. F. (2021). Use of Noncustodial Measure and Independent Monitoring Body as Panacea to Awaiting-Trial Problems in Ebonyi State, Nigeria. International Journal of Criminal Justice Sciences, 16 (1), 5163.

Okiro, M. (2005).Proliferation of illegal arms and ethno-religious violence in Nigeria. Lagos: CLEEN Foundation.

Okpa, J. T., Ajah, B. O, \& Okunola, R. A. (2018). Religious fundamentalism and sustainable development in Nigeria: understanding the intricacies. Journal of Religion and Theology, 2 (2), 12-18.

Olalekan, A., Olokor, F., Hanafi, A., \& Charles, J. (2018, May 1). killing of Christians in Nigeria must stop, says Trump. Punch Newspaper, p 56.

Rolando Y, W. (2017). Religious Beliefs In Nigeria. Worldatlas. Retrieved from https://www.worldatlas.com/articles/religiousbeliefs-in-nigeria.html
Sahara Reporters. (2016). How Suspected Muslim Fanatics Hacked Female Redeemed Church Preacher To Death In Abuja. Retrieved from http://saharareporters.com/2016/07/11/howsuspected-muslim-fanatics-hacked-female-redeemedchurch-preacher-death-abuja

Sani, T. (2016, May $16^{\text {th }}$ ). Shocking revelation: 100,000 killed, two million displaced by Boko Haram insurgency, Borno Governor says. Premium Newspaper, p45.

Sontag, F. (1990). Political violence and liberation theology. JETS, $33(1), 85-94$.

Sulaiman, K. O. (2016). Religious violence in contemporary Nigeria: implications and options for peace and stability order. Journal for the Study of Religion, 29 (1) 85 - 103.

Sulaiman, K.O. (2004). Jerusalem as a uniting factor for Muslims and Christians: historical and scriptural grounds. The IAFOR Journal of Arts and Humanities, 2 (1), 39-45. https://doi.org/10.22492/ijah.2.1.04

The Guardian (2013, July 2). Doesn't religion cause most of the conflict in the world? Guardian, P13.

Ugwuoke, C. O., Ajah, B. O., \& Onyejegbu, C. D. (2020). Developing patterns of violent crimes in Nigerian democratic transitions. Aggression and Violent Behavior, 53, 1-8. https://doi.org/10.1016/j.avb.2020.101457

UK Parliament. (2003). Select Committee on Religious Offences in England and Wales. Retrieved from https://publications. parliament.uk/pa/ld200203/ldselect/ldrelof/95/9517.htm

Urban Dictionary. Retrieved from https://www.urbandictionary.com/ define.php?term=religious $\% 20$ fanatic

Vivian, F. (2018). History of How Christianity came to Nigeria. Retrieved from https://www.legit.ng/1145690-historychristianity-nigeria.html

Wantu, J. (2018, 25 April). Suspected herdsmen kill two Catholic priests, 17 others. The Guardian, P37.

World Watch Monitor. (2018). Nigeria: Pastor and three sons burned alive among at least 20 killed in latest Plateau massacre. Retrieved from https://www.worldwatchmonitor.org/2018/ 09/nigeria-pastor-and-three-sons-burned-alive-among-atleast-20-killed-in-latest-plateau-massacre/

Received on 04-08-2021

https://doi.org/10.6000/1929-4409.2021.10.158

(C) 2021 Enweonwu et al.; Licensee Lifescience Global.

This is an open access article licensed under the terms of the Creative Commons Attribution License (http://creativecommons.org/licenses/by/4.0/) which permits unrestricted use, distribution and reproduction in any medium, provided the work is properly cited. 